Gut, 1962, 3, 129

\title{
An experimental study of gastric cancer in relation to gastric ulcer
}

\author{
R. STEIN-WERBLOWSKY
}

From the Marie Curie Hospital, London

EDITORIAL SYNOPSIS This experimental study shows that carcinogens are relatively harmless on intact gastric mucosa but can induce lesions when the mucosa has been damaged, particularly when the injury is deep as in gastrostomy. Human gastric carcinogenesis is discussed in the light of these findings.

The question whether gastric ulcer is a precursor of gastric cancer has not yet been resolved with certainty. Various authors feel that on the grounds of clinical observation a definite correlation exists between these two entities (Pack et al., 1950; Horn and Ravdin, 1953; Ivy, 1955; Monges, Payan, Bonneau, and Saint Pierre, 1960; Henschen, 1960; Ringertz, 1961) but observations on animals have failed to decide this question as spontaneous gastric ulcers and gastric tumours are rare in laboratory animals. There are, however, certain recent reports on spontaneous tumours of the stomach in mice (Wells, Slye, and Holmes, 1938; Miller and Pybus, 1956; Fischer and Kühl, 1958).

Several methods have been devised to induce experimental cancer of the stomach in laboratory animals, such as feeding carcinogenic hydrocarbons (Mulay and Firminger, 1952; Bock and King, 1959), adding certain solvents to peroral carcinogens (Peacock, Beck, and Chalmers, 1953; Setälä and Ekwall, 1950; Shemiakina, 1959), intramural injection of carcinogens (Stewart and Lorenz, 1942; Stewart and Hare, 1950; Hare, Stewart, Bennett, and Lorenz, 1952), or insertion of a carcinogenimpregnated thread into the stomach wall (Howes and de Oliveira, 1948; Ritchie, Webster, and Skoryna, 1959; Skoryna and Ritchie, 1960). Attempts to induce gastric cancer at the site of experimental gastric ulcer in rabbits have been unsuccessful (Ivy and Cooke, 1947; Denton, Sheldon, and Ivy, 1950).

The object of the present paper is to study once more the correlation between gastric ulcer and gastric cancer and to show that a carcinogen can induce local cancer when applied directly on the injured or ulcerated gastric mucosa in the rat, but not when it is applied to the intact mucous membrane of the stomach.

\section{MATERIALS AND METHODS}

Experiments were carried out on 272 white Wistar rats obtained commercially and weighing 150 to $180 \mathrm{~g}$. They were housed in cages of six and fed on diet 41 rat cubes and water ad lib.

The carcinogens used were methylcholanthrene and dimethylbenzanthracene (Light \& Co.) in powder form or dissolved in olive oil $(75 \mathrm{mg}$. methylcholanthrene in $2 \mathrm{ml}$. olive oil).

Group A, consisting of 69 rats, was fed by stomach tube and each rat received one intragastric instillation of $75 \mathrm{mg}$. methylcholanthrene in olive oil, without further injury to the gastric mucosa.

Groups B, C, and D were all subjected to gastrostomies. Food hoppers were removed the night before operation. Anaesthesia was induced by intraperitoneal injection of nembutal Abbott. The stomach was incised and, after treatment, sutured with fine nylon thread. For the first two or three postoperative days the animals were fed on a diet of bread and milk. The carcinogen was delivered to the fore or glandular stomach using a probe topped with cotton wool which had been dipped in dimethylbenzanthracene powder. Approximately $1 \mathrm{mg}$. of carcinogen was delivered by this method. The surgical procedure varied in each group.

Group B consisted of 90 animals. Gastrostomy was performed on the squamo-glandular junction of the stomach and the squamous epithelium folded back. In the experimental animals ulcers were induced by scraping an area of about $2 \mathrm{~mm}$. off the mucosa in the forestomach with a scalpel or painting it with concentrated caustic soda. The area so injured was then dusted with dimethylbenzanthracene powder. Twelve of the control animals were treated with caustic soda only and 28 with dimethylbenzanthracene only without prior ulceration.

In the course of the experiment it was observed that some cancers developed at the gastrostomy site and the technique was subsequently modified to avoid contact between carcinogen and gastrostomy site.

Group C consisted of 59 rats. The gastrostomy was 
made in the prepyloric part of the stomach and an aural speculum passed through the incision; injury to the membrane and carcinogenic treatment to the forestomach were the same as in Group B, with the difference that all these procedures were carried out through the speculum.

Group D consisted of 54 rats. The procedure was identical with that in Group C, but the mode of application was reversed, i.e., gastrostomy was performed on the forestomach and the glandular stomach subjected to the carcinogenic treatment.

The animals were killed whenever tumours were palpated in the abdomen or whenever they were found to be ill or suffering.

\section{RESULTS}

The rats survived for periods varying from five to 26 months, the average being 16 months. The most frequent causes of death were pneumonia or gastrointestinal abscesses.

From Table I it can be seen that no gastric lesion developed in animals receiving the carcinogen in a single gastric instillation but the carcinogen must have been absorbed into the gastrointestinal tract as five extragastric tumours were found in this series.

Table II shows the lesions in animals undergoing gastrostomy of the squamo-glandular junction. It is probable that the carcinogen was in intimate
TABLE I

LESIONS IN 69 ANIMALS RECEIVING ONE INTRAGASTRIC DOSE OF METHYLCHOLANTHRENE

\begin{tabular}{llc}
$\begin{array}{l}\text { Gastric } \\
\text { Lesions }\end{array}$ & Extragastric Lesions & $\begin{array}{l}\text { Time } \\
\text { (months) }\end{array}$ \\
\hline None & Reticulo-sarcoma in the thorax & 12 \\
None & Reticulo-sarcoma in the thorax & 12 \\
None & Reticulo-sarcoma in the thorax & 12 \\
None & Mammary adenoma & 12 \\
None & $\begin{array}{l}\text { Hypertrophy of the mammary gland secretion } \\
\text { of milk }\end{array}$ & 12
\end{tabular}

contact with the gastrostomy site as the stomach was seen to contract after handling. The incidence of local lesions was $22 \%$ in the experimental animals and $21 \%$ in the carcinogen-treated controls.

From Table III it can be seen that only two of 32 experimental animals developed any lesions in the forestomach and these were benign. In the control series there was one case of metastatic sarcoma of the glandular stomach. This was probably due to accidental implantation of the carcinogen in the gastrostomy site as the intention was to apply the carcinogen to the forestomach only.

Table IV gives the results in rats whose glandular stomach was subjected to carcinogenic treatment. These animals had to be sacrificed at eight months of the experiment when the laboratory was closed.

TABLE II

LESIONS IN 50 ANIMALS WITH GASTROSTOMY AT SQUAMO-GLANDULAR JUNCTION FOLLOWED BY ULCERATION AND CARCINOGENIC TREATMENT OF FORESTOMACH

Gastric Lesions

Time (months)

Metastatic cancer (forestomach)

Metastatic cancer (forestomach)

Metastatic cancer (forestomach)

Metastatic adenocarcinoma

Cancer

Sarcoma of glandular stomach $(85 \mathrm{~g}$.)

Papilloma with malignant changes of forestomach

Papilloma of forestomach

Papilloma of forestomach

Papilloma of forestomach

Papilloma of forestomach
Extragastric Lesions

Time (months)

Intestinal sarcoma

Sarcoma of abdominal wall

Sarcoma of abdominal wall

Mammary fibroma

Mammary fibroma

Fibroid of cervix uteri

Wart of the lip

TABLE IIA

LESIONS IN 40 CONTROLS

Gastric Lesions

Time (months)

Extragastric Lesions

Time (months)

Gastrostomy and dimethylbenzanthracene only (28 rats)

Carcinoma of forestomach

Carcinoma of forestomach

Sarcoma of glandular stomach $(80 \mathrm{~g}$.

Sarcoma of glandular stomach

Papilloma of forestomach

Papilloma of forestomach

Sarcoma of abdominal wall

Sarcoma of abdominal wall

Mammary fibroma

Cervical fibroma

Gastrostomy and $\mathrm{NaOH}$ only (12 rats)

No lesions 


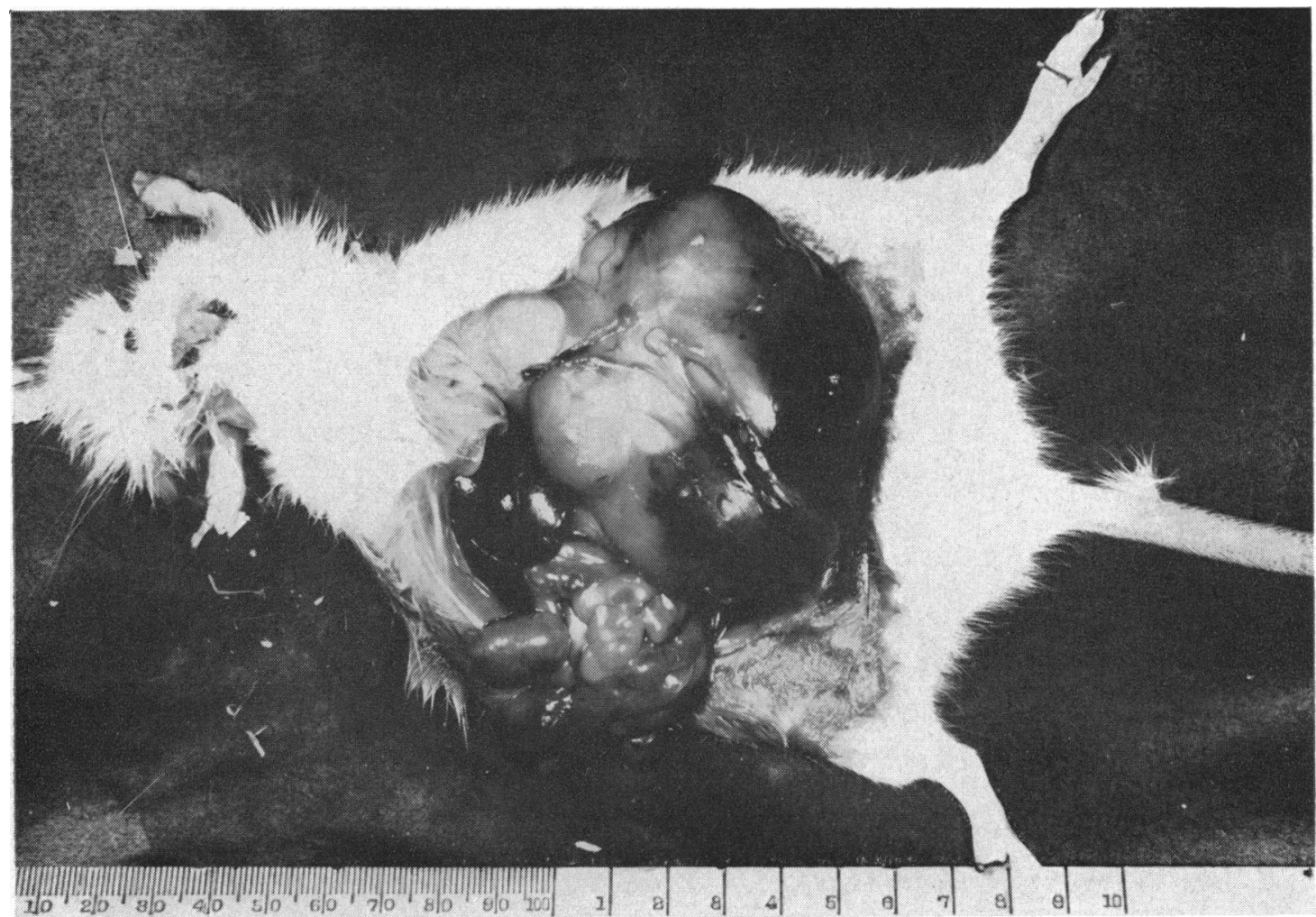

FIG. 1. Sarcoma of the glandular stomach weighing $80 \mathrm{~g}$. (8 months).

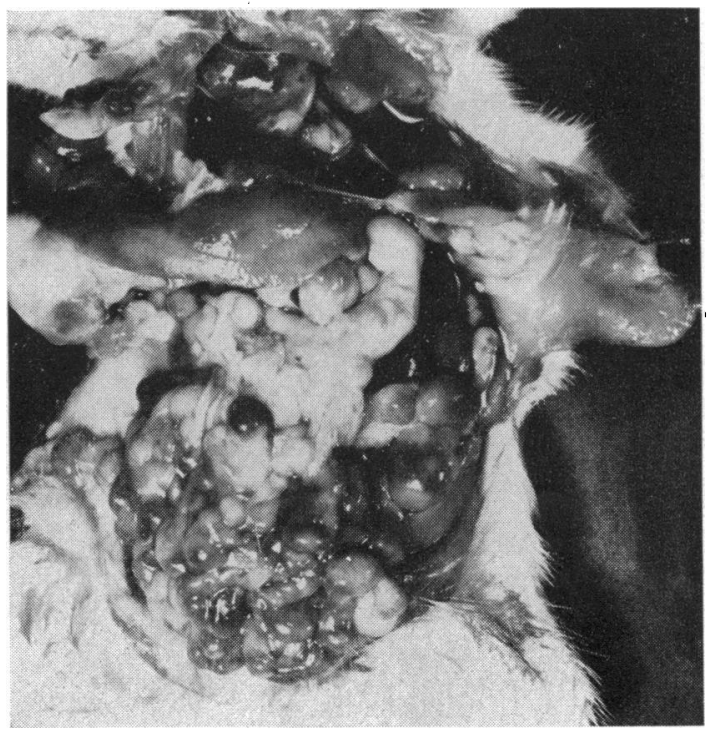

FIG. 2. Metastatic sarcoma of the glardular stomach (8 months). 


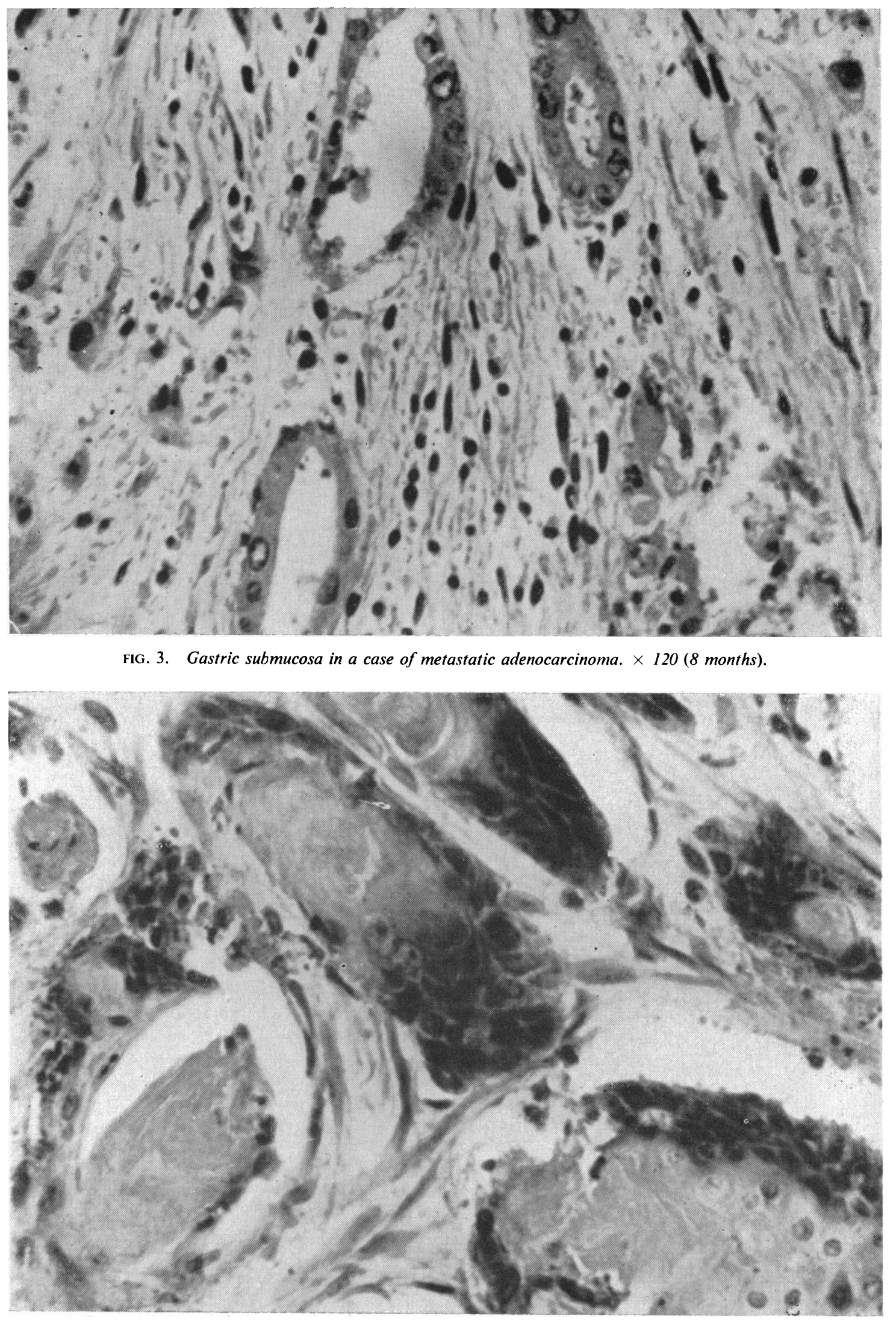

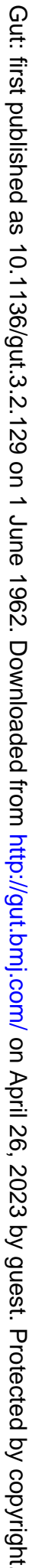

FIG. 4. Keratinizing squamous carcinoma of forestomach. $\times 120$. 
TABLE III

LESIONS IN 32 EXPERIMENTAL ANIMALS WITH GASTROSTOMY OF PRE-PYLORIC STOMACH AND ULCERATION AND DIMETHYLBENZANTHRACENE POWDER ON FORESTOMACH

\begin{tabular}{lccc} 
Gastric Lesions & Time (months) & Extragastric Lesions & Time (months) \\
\hline Ulcer of glandular stomach & 16 & Lymphoma of caecum \\
Papilloma of forestomach & 12 & 12
\end{tabular}

TABLE IIIA

LESIONS IN 27 CONTROLS

Gastric Lesions

Time (months)

Extragastric Lesions

Time (months)

Dimethylbenzanthracene only (18 rats)

Metastatic sarcoma of glandular stomach

14

$\mathrm{NaOH}$ only $(9$ rats $)$

No lesions

Within that period two cases of metastatic sarcoma of the glandular stomach were observed in the experimental group. There were no lesions among the controls.

\section{TABLE IV}

LESIONS IN 34 EXPERIMENTAL ANIMALS WITH GASTROSTOMY OF FORESTOMACH AND ULCERATION AND DIMETHYLBENZANTHRACENE POWDER ON GLANDULAR STOMACH

\begin{tabular}{lccc} 
Gastric Lesions & $\begin{array}{l}\text { Time } \\
\text { (months) }\end{array}$ & Extragastric Lesions & $\begin{array}{l}\text { Time } \\
\text { (months) }\end{array}$ \\
\hline $\begin{array}{l}\text { Metastatic sarcoma } \\
\text { Metastatic sarcoma }\end{array}$ & 6 & None &
\end{tabular}

TABLE IVA

LESIONS IN 20 CONTROLS WITH GASTROSTOMY IN FORESTOMACH AND DIMETHYLBENZANTHRACENE POWDER ON GLANDULAR STOMACH

\begin{tabular}{llc} 
Gastric Lesions & Extragastric Lesions & Time (months) \\
\hline None & Ovarian abscess & 7
\end{tabular}

\section{DISCUSSION}

From the above data it appears that the animals in which the carcinogen was allowed to act on the gastrostomy site (group B) or on experimental gastric ulcers had a much higher incidence of gastric tumours than those where the carcinogen was applied to the intact gastric mucosa.

Trauma enhances the effects of chemical carcinogens on skin (Deelman, 1927; MacKenzie and Rous, 1941; Pullinger, 1943, 1945; Linell, 1947; Breedis, 1955; Gottfried, Molomut, and Patti, 1961) and it is probable that the same holds true for other epithelia, including stomach.

The decisive factor in malignant transformation
Reticulo-sarcoma in the thorax

9

No lesions

appears to be the intimate contact between the basal or stem cell, or young regenerating elements, and the carcinogen, such as is possible in areas of ulceration, abrasion, or wound repair.

The experimental gastric tumours obtained by various methods have probably been elicited by similar mechanisms. Simple feeding of carcinogens has not produced gastric adenocarcinomata (Peacock et al., 1953) but the intramural introduction of such substances has caused tumours of the glandular stomach (Stewart and Lorenz, 1942; Howes and de Oliveira, 1948). Similarly, the addition of certain agents with lipophilic or hydrophylic properties to peroral carcinogens greatly increased the incidence of gastric tumours (Setälä and Ekwall, 1950; Berenblum and Haran, 1955; Shemiakina, 1959; Arffmann, 1960). Ivy (1955) offers the following explanation: 'For methylcholanthrene to cause cancer of the stomach it must act on the deeper cells of the gastric glands or the carcinogen must be sufficiently soluble to be absorbed into the deeper cells'.

The genesis of gastric cancer in man might be compared with what happens under experimental conditions, namely, exposure of basal or regenerating cells, such as is possible in atrophic gastritis or ulceration, to exogenous dietary carcinogens. Clinical gastric cancer may only emerge after a long latent quiescent period so that the primary episode of gastric ulceration might no longer be associated with it. On the other hand, the ulcer coexisting with the cancer will probably not be the one to have undergone malignant change. Pack et al. (1950) and Willis (1953) insist that cancer has rarely been found on the edges of gastric ulcer and that therefore no correlation exists between the two.

It is significant that similar observations have been made on the colon. As many as one-third of longstanding cases of ulcerative colitis eventually develop 
malignant changes. Svartz and Gillnäs (1958), Rosenquist, Öhrling, Lagercrantz, and Edling (1959), and Reiferscheid (1960) stress the presence of a long period of apparent good health before the emergence of cancer of the colon. A similar course of events was reported in a case of ulceration of the rectum preceding rectal cancer (Simianovskii, 1959).

I wish to express my thanks to Mrs. P. David and Mr. Mass N'jie for skilful technical assistance and to Mr. Eric Saville for the photographs.

\section{REFERENCES}

Arffmann, E. (1960). Heated fats and allied compounds as carcinogens; a critical review of experimental results. J. nat. Cancer Inst., 25, 893-926.

Berenblum, I., and Haran, N. (1955). The influence of croton oil and of polyethylene glycol-400 on carcinogenesis in the forestomach of the mouse. Cancer, Res., 510-516.

Bock, F. G., and King, D. W. (1959). A study of the sensitivity of the mouse forestomach toward certain polycyclic hydrocarbons. J. nat. Cancer Inst., 23, 833-839.

Breedis, C. (1955). Early carcinogenesis in regenerating rabbit skin with 9,10 dimethyl-1,2-benzanthracene. Proc. Amer. Ass. Cancer Res., 2, 7.

Deelman, H. T. (1927). The part played by injury and repair in the development of cancer, with some remarks on the growth of experimental cancers. Proc. roy. Soc. Med., 20, 1157-1158.

Denton, R. W., Sheldon, P., and Ivy, A. C. (1950). Attempts to produce gastric carcinoma experimentally in a gastric ulcer. Cancer Res., 10, 684-685.

Fischer, W., and Kühl, I. (1958). Geschwülste der Laboratoriumsnagetiere. Steinkopff, Dresden.

Gottfried, B., Molomut, N., and Patti, J. (1961). Effect of repeated surgical trauma on chemical carcinogenesis. Cancer Res., 21, 658-660.

Hare, W. V., Stewart, H. L., Bennett, J. G., and Lorenz, E. (1952). Tumors of the glandular stomach induced in rats by intramural injection of 20-methylcholanthrene. J. nat. Cancer Inst., 12, 1019-1055.

Henschen, F. (1960). Die Pathogenese des Magenkrebses. Arch. De Vecchi Anat. pat., 31, 149-162.

Horn, R. C., Jr., and Ravdin, I. S. (1953). The relationship of gastric ulcer to gastric cancer. J. nat. Cancer Inst., 13, 1049-1063.

Howes, E. L., and de Oliveira, J. R. (1948). Early changes in the experimentally produced adenomas and adenocarcinomas of the stomach. Cancer Res., 8, 419-427.

Ivy, A. C. (1955). Experimental observations on the etiology of gastric carcinoma. Gastroenterology, 28, 325-359.

- , and Cooke, A. (1947). An attempt to produce malignant transformation of gastric ulcers in rabbits. A preliminary report. J. nat. Cancer Inst., 7, 345-348.
Linell, F. (1947). On the tumour promoting effect of a single mechanical trauma. An experimental study on skin tumours in tarred rabbits. Acta path. Microbiol. scand., Suppl. 71.

MacKenzie, I., and Rous, P. (1941). The experimental disclosure of latent neoplastic changes in tarred skin. J. exp. Med., 73, 391-415.

Miller, E. W., and Pybus, F. C. (1956). Hyperplastic and neoplastic lesions of the glandular stomach and intestine in 2 inbred strains of mice and their reciprocal hybrids. Brit. J. Cancer, 10, 89-109.

Monges, H., Payan, H., Bonneau, H., and Saint Pierre, A. (1960). Note sur la fréquence de la cancérisation de l'ulcère gastrique, d'après l'étude histologique de 776 cas d'ulcère gastrique. Arch. Mal. Appar. Dig., 49, 651.

Mulay, A. S., and Firminger, H. I. (1952). Precancerous and cancerous lesions of the forestomach and dermal-cutaneous tumors in rats fed $p$-dimethyl-aminobenzene-1-azo - 1-naphthalene. J. nat. Cancer Inst., 13, 57-71.

Pack, G. T. et al. (1950). Panel discussion-The relationship of gastric ulcer to gastric cancer. Cancer, 3, 515-552.

Peacock, P. R., Beck, S., and Chalmers, J. G. (1953). Gastric cancer: possible dietary carcinogens. J. nat. Cancer Inst., 13, 931-947.

Pullinger, B. D. (1943). The localisation of experimental tumours in scars and healing wounds. J. Path. Bact., 55, 301-309.

- (1945). An experimental approach to the problem of trauma and tumours. Ibid., 57, 467-476.

Reifferscheid, M. (1960). Das Spätschicksal des Colitis ulcerosaKranken. Arch. klin. Chir., 293, 558-570.

Ringertz, N. (1961). The pathology of gastric cancer and its relationship to gastritis, polyps and ulcer. Acta Un. int. Cancr., 17, 289-295.

Ritchie, A. C., Webster, D. R., and Skoryna, S. C. (1959). The differentiation between benign and malignant gastric lesions in the rat. Proc. Amer. Ass. Cancer Res., 3, 57.

Rosenquist, H., Ohrling, H., Lagercrantz, R., and Edling, N. (1959). Ulcerative colitis and carcinoma coli. Lancet, 1, 906.

Setälä, K., and Ekwall, P. (1950). Some observations on chemica carcinogenesis using new types of solvents for the carcinogenic hydrocarbons. Acta Un. int. Cancr., 7, 160-166.

Shemiakina, T. V. (1959). The importance of the solvent and mode of administration of a carcinogenic substance in inducing experimental cancer of the fore-stomach of mice. Problems of Oncology, 5, No. 9, pp. 88-97.

Simanovskii, M. A. (1959). Rectal carcinoma developed from an ulcer. Ibid., 5, No. 1, pp. 143-146.

Skoryna, S. C., and Ritchie, A. C. (1960). The experimental production of adenocarcinoma of the stomach in rats. Gastroenterology, 39, $737-746$.

Stewart, H. L., and Lorenz, E. (1942). Adenocarcinoma of the pyloric stomach and other gastric neoplasms in mice induced with carcinogenic hydrocarbons. J. nat. Cancer Inst., 3, 175-189.

_- and Hare, W. V. (1950). Variation in susceptibility of the fundic and pyloric portions of the glandular stomach of the rat to induction of neoplasia by 20 methylcholanthrene. Acta Un. int. Cancr., 7, 176-177.

Svartz, N., and Gillnäs, T. (1958). In which phase of ulcerative colitis does colonic cancer occur? Amer. J. dig. Dis., n.s. 3, 537-548.

Wells, H. G., Slye, M., and Holmes, H. F. (1938). Comparative pathology of cancer of the alimentary canal, with report of cases in mice. Amer. J. Cancer, 33, 223-238.

Willis, R. A. (1953). Pathology of Tumours, 2nd ed., p. 394. Butterworth, London. 